\title{
The Use of Single-Cell Comet Assay on Oral Cells: A Critical Review
}

\author{
ANA CAROLINA FLYGARE SOUZA, VERONICA QUISPE YUJRA, LUCIANA PELLEGRINI PISANI, \\ MILENA DE BARROS VIANA, GLAUCIA MONTEIRO DE CASTRO and DANIEL ARAKI RIBEIRO \\ Departments of Biosciences, Federal University of São Paulo, UNIFESP, Santos, SP, Brazil
}

\begin{abstract}
Background/Aim: Genotoxicity is the capacity of an agent to induce damage to DNA. Given the close relationship between genotoxicity and carcinogenesis, several assays have been developed for detecting genetic damage. Among them, the single-cell gel (comet) assay plays an important role for evaluating DNA damage in mammalian cells, including those of the oral cavity. The purpose of this article was to provide a critical review of the application of single-cell gel comet assay to buccal cells. Material and Methods: A search of the scientific literature was conducted of published studies available on single-cell gel comet assay and oral cells. Results: The results showed that the majority of studies were conducted on humans, whereas few were designed for use in rodents and in vitro. Conclusion: Further studies within the field are relevant for better understanding the underlying mechanisms of genotoxicity in oral cells, especially since the use of humans is quite complicated due to issues of ethics.
\end{abstract}

Genotoxicity is the ability of an agent to promote genetic damage. This means that a harmful agent is only considered genotoxic if it is able to interact with genetic material. Currently, several substances either from endogenous or exogenous sources are identified as genotoxic in the scientific literature. For this reason, it is assumed that different agents present in the environment can damage the human genome. Fortunately, eukaryotic cells are highly specialized with respect to being able to prevent and even neutralize genotoxic damage as well as repair DNA. To fulfill this purpose, the

Correspondence to: Professor Daniel A. Ribeiro, Department of Biosciences, Federal University of Sao Paulo, UNIFESP, Rua Silva Jardim, 136, Room 332, Vila Mathias, Santos - SP, 11050-020, Brazil. Tel: +55 1332290156, e-mail: daribeiro@unifesp.br

Key Words: Single-cell gel comet assay, oral cells, genotoxicity, DNA damage, review. xenobiotic metabolizing system and DNA repair system play a crucial role in protecting the integrity of the human genome (1). Considering the close relationship between genotoxicity and carcinogenesis, the approach is very important for protecting humans against any potential harm.

There are several methodologies used by the scientific community capable of detecting genetic damage and mutations as a wide range of end-points, such as: DNA strand breaks, DNA adducts, point mutations, chromosomal translocations, chromosomal loss or interference with spindle-cell apparatus and the DNA repair system (2). This information is relevant for clarifying potential human health risks posed by genotoxic agents. Among them, the single-cell gel comet assay is a promising tool for evaluating genetic damage in mammalian cells (3). It was initially developed by Ostling and Johanson (4) and Singh et al. (5). Given the relative simplicity and low costs when compared to other methods for the same purpose, the technique has been validated over the years by many research groups around the world (6-8). In brief, the methodological procedure consists of embedding cells in agar, followed by cell membrane removal using lysis solution; the DNA is allowed to unwind, and electrophoresis is then performed at a high alkaline $\mathrm{pH}(\mathrm{pH}>13)$. Loops of DNA and strand breaks relax, being attracted toward the anode, with the typical appearance of a comet composed of a head and tail (3). In particular, the presence of a tail in the comet image represents strand breaks of DNA.

Lymphocytes are considered the gold standard for use in the single-cell gel comet assay (3). Nevertheless, it would be especially useful and interesting to investigate genotoxicity in epithelial cells by means of single-cell gel comet assay, since epithelial cells are the most common tissues documented in the literature as undergoing malignant transformation (9).

Considering the relevance of the arguments mentioned above, especially the importance of the single-cell gel comet assay on buccal cells for evaluating harmful effects on human health, the aim of this study was to search for scientific articles published on this procedure for the analysis of exfoliated cells 
from the oral mucosa in mammals up until 2019. In particular, the study focused on three aspects: (i) The experimental design adopted by the studies, (ii) the main genotoxicity inducer studied, and (iii) the topographic distribution of articles published in the literature, for the application of this test for protecting humans against potential harm (10).

\section{Materials and Methods}

Scientific literature search. The present study conducted a search of the scientific literature of published studies available in in PUBMED, MEDLINE, EMBASE and Google scholar for all kind of articles (all publications to May, 2019) and was carried out using the following key words: single-cell gel comet assay, oral cells, buccal cells, oral mucosa. No time limit was imposed on the search in order to identify the maximum number of articles published in the scientific literature. Review articles, case reports and articles not written in the English language were excluded from the study. All articles were identified by title, year of publication, subject and type of experimental design (human in vivo; rodent in vivo; and in vitro). The following subjects were considered in the analysis: dentistry; pollution; cancer; smoke; illicit drugs, chemicals/drugs; aging; standardization and radiation. Abstracts were reviewed and relevant articles were identified.

Statistical analysis. In order to determine whether there was an increase in the number of articles published on single-cell gel comet assay and oral cells, Pearson's correlation coefficient was calculated between the year (dependent variable) and the number of articles published. Data analyses were carried out using SPSS software, version 10.0 (Chicago, IL, USA). Values of $\mathrm{p}<0.05$ were considered for statistical significance.

\section{Results and Discussion}

A total of 129 articles were retrieved for the period between 1996 and 2019, but only 54 fulfilled the requirements adopted in this setting (Table I). The first article published in the field was by Rojas et al., who detected the presence of genetic damage to oral cells of smokers (11). From there, several articles with use of single-cell gel comet assay on buccal mucosa cells were identified.

Regarding the temporal perspective, the total number of articles published $(n=54)$ were distributed homogeneously over the years. The year 2011 stands out, in which seven articles were published. Next, it is noteworthy that from 2012 to 2015, five articles were published. The correlation test did not show statistically significant correlation in publication frequency with time $(\mathrm{r}=0.13, p=0.55)$.

The topographical distribution of articles revealed that Europe was the continent that published the most articles, with a total of 20 articles, followed by Latin America (15 papers) and Asia (13 papers). In Europe, the following countries were highlighted: Germany $(n=7)$ and Italy $(n=6)$. In Latin America, only Brazil and Mexico published articles on using the single-cell gel comet assay on oral mucosa cells. In Asia, the vast majority of scientific production within the field was made by China and India. Such findings are demonstrated in Table II.

According to the experimental design, the majority of studies were human in vivo $(\mathrm{n}=39)$. The use of buccal mucosa cells from experimental animals (rodents) only comprised eight published articles. Similarly, there were only five articles on in vitro studies using single-cell gel on oral cells.

Considering that the single-cell gel comet assay has been ideally designed for peripheral blood cells, in particular lymphocytes, its use for epithelial cells required further standardization in order to overcome possible pitfalls in methodology. Some authors have struggled to ensure the reproducibility of the modified assay. After searching the literature, five articles discussing the standardization of the single-cell gel comet assay oral cells were found. Pinhal et al. have demonstrated that the majority of comets are leukocytes and not buccal cells when performing the singlecell gel comet assay (12). These findings were confirmed by other studies (13). However, others have also successfully standardized the methodology, concluding that it is able to detect genetic damage in epithelial cells (9).

Nevertheless, the great majority of studies were dedicated to dentistry, i.e. investigations on genotoxic effects of dental treatments or even chemicals used in dental practice on oral mucosa cells. The genotoxicity of orthodontic therapy has been evaluated by many studies so far. For example, Faccioni et al. demonstrated DNA damage in oral mucosa cells in patients undergoing orthodontic treatment $(14,15)$. Others also detected DNA damage in oral mucosal cells as a result of metals released by orthodontic devices in the oral cavity $(16,17)$. However, Westhphalen et al. were not able to detect genetic damage in oral mucosal cells following orthodontic therapy (18). Therefore, genotoxicity induced by orthodontic devices is still a matter of debate. Other products for oral health, such as mouthwashes, were also investigated. The results demonstrated that alcohol-containing mouthwashes were genotoxic in vitro (19). In humans and rodents, the results were similar $(20,21)$.

The next purpose of investigation within the field was head and neck cancer, more specifically oral cancer pathogenesis. After searching the literature, some articles on in vivo and in vitro studies were found. The first study investigated DNA damage in oral cells following mediumterm chemical carcinogenesis in rats and was conducted by Ribeiro et al. (22). The authors demonstrated genetic damage in oral mucosa cells following rat tongue carcinogenesis induced by 4 nitroquinoline-1-oxide (22). Some years later, the same authors demonstrated that oxidative DNA damage is present on oral cells undergoing malignant transformation in vivo $(23,24)$.

Thereafter, other studies aimed to investigate whether cigarette smoke damages oral cells. The approach is 
Table I. Publications regarding single-cell gel comet assay on buccal cells in chronological order.

\begin{tabular}{|c|c|c|c|c|}
\hline Author(s) & Year of publication & Field of study & Experimental design & Ref. \\
\hline Faccioni et al. & 2019 & Dentistry & Human in vivo & 14 \\
\hline Kapadia et al. & 2018 & Dentistry & Human in vivo & 16 \\
\hline Fox et al. & 2018 & Dentistry & In vitro & 19 \\
\hline Vasquez-Boucard et al. & 2017 & Pollution & Human in vivo & 33 \\
\hline Carbajal-Lopes et al. & 2016 & Pesticides & Human in vivo & 46 \\
\hline Gonçalves et al. & 2015 & Dentistry & Human in vivo & 47 \\
\hline Wessels et al. & 2015 & Dentistry & In vitro & 48 \\
\hline Martin-Camean et al. & 2015 & Dentistry & Human in vivo & 49 \\
\hline Bhagwath and, Chandra & 2015 & Oral cancer pathogenesis & Human in vivo & 50 \\
\hline Al-Amrah et al. & 2014 & Smoke & Human in vivo & 26 \\
\hline Feretti et al. & 2014 & Pollution & Human in vivo & 51 \\
\hline How et al. & 2015 & Pesticides & Human in vivo & 30 \\
\hline Koller et al. & 2014 & Cannabimimetic drug & In vitro & 41 \\
\hline Pozzi et al. & 2013 & Nandrolone decanoate & Rodents in vivo & 29 \\
\hline Eshkoor et al. & 2013 & Aging & Human in vivo & 43 \\
\hline Visalli et al. & 2013 & Dentistry & Human in vivo & 52 \\
\hline Pal et al. & 2012 & Smoke and Black tea & Human in vivo & 37 \\
\hline Szeto et al. & 2012 & Standardization & Human in vivo & 53 \\
\hline Carvalho et al. & 2012 & Oral cancer pathogenesis & Rodents in vivo & 23 \\
\hline Dodani et al. & 2012 & Oral cancer pathogenesis & Human in vivo & 54 \\
\hline Baricevic et al. & 2012 & Dentistry & Human in vivo & 55 \\
\hline De Oliveira et al. & 2011 & Occupational exposure & Human in vivo & 31 \\
\hline Mukherjee et al. & 2011 & Oral cancer pathogenesis & Human in vivo & 27 \\
\hline Sudha et al. & 2011 & Metals & Human in vivo & 56 \\
\hline Mondal et al. & 2011 & Pollution and smoke & & 34 \\
\hline Fernandez-Minano et al. & 2011 & Dentistry & Human in vivo & 17 \\
\hline Miranda et al. & 2011 & Oral cancer pathogenesis & Rodents in vivo & 24 \\
\hline Muniz et al. & 2011 & Standardization & Human in vivo & 57 \\
\hline Reiter et al. & 2010 & Orophangeal cancer & In vitro & 58 \\
\hline Baumeister al. & 2009 & Head and neck cancer & In vitro & 59 \\
\hline Baumeister et al. & 2009 & Epigallocathechin and smoke & In vitro & 38 \\
\hline Chung et al. & 2009 & Oral cancer therapeutics & Rodents in vivo & 39 \\
\hline Pereira et al. & 2009 & Natural products & In vitro & 40 \\
\hline Westphalen et al. & 2008 & Dentistry & Human in vivo & 18 \\
\hline Abdel-Kader et al. & 2008 & Dentistry & Human in vivo & \\
\hline Saran et al. & 2008 & Oral cancer pathogenesis & Human in vivo & 28 \\
\hline $\mathrm{Pal}$ et al. & 2007 & Black tea and smoke & Human in vivo & 37 \\
\hline Ursini et al. & 2006 & Occupational exposure & Human in vivo & 32 \\
\hline Cavallo et al & 2006 & Occupational exposure & Human in vivo & 35 \\
\hline He and Chen & 2006 & Fluoride & Rodent in vivo & 45 \\
\hline Pinhal et al. & 2006 & Standardization & Human in vivo & 12 \\
\hline Szeto et al. & 2005 & Standardization & Human in vivo & 9 \\
\hline Glei et al. & 2005 & Smoke & Human in vivo & 25 \\
\hline Ribeiro et al. & 2004 & Fluoride & Rodent in vivo & 44 \\
\hline Ribeiro et al. & 2004 & Oral cancer pathogenesis & Rodent in vivo & 22 \\
\hline Ribeiro et al. & 2004 & Dentistry & Rodent in vivo & 21 \\
\hline Dhillon et al. & 2004 & Radiation & Rat in vivo & 42 \\
\hline Martino-Roth et al. & 2003 & Occupational exposure & Human in vivo & 36 \\
\hline Faccioni et al. & 2003 & Dentistry & Human in vivo & 15 \\
\hline Osswald et al. & 2003 & Standardization & Human in vivo & 13 \\
\hline Eren et al. & 2002 & Dentistry & Human in vivo & 20 \\
\hline Kleinsasser et al. & 2001 & Phthalates & In vitro & 60 \\
\hline Tomakidi et al. & 2000 & Dentistry & In vitro & 61 \\
\hline Rojas et al. & 1996 & Smoke & Human in vivo & 11 \\
\hline
\end{tabular}


Table II. Geographic distribution of published articles on single-cell gel comet assay of oral cells.

\begin{tabular}{lc}
\hline Region & Number of articles published $(\mathrm{n}=54)$ \\
\hline Africa & 1 \\
Asia & 14 \\
Europe & 20 \\
Latin America & 15 \\
Middle East & 2 \\
Oceania & 2 \\
North America & 1 \\
\hline
\end{tabular}

relevant since cigarette smoke is the main preventable cause of oral carcinogenesis. Thus, some authors demonstrated a positive association between smoking and the presence of DNA damage in oral cells $(11,25,26)$. These findings suggest that agents in cigarette smoke are potent genotoxins and therefore protagonists in oral cancer pathogenesis, during the initiation phase of carcinogenesis. Mukherjee et al. detected DNA damage in oral cells from patients suffering leukoplakia and oral squamous cell carcinoma (27). Taken as a whole, such lesions are capable of generating genomic instability in the buccal mucosa and can therefore contribute to the progression of the disease. The results are in agreement with those published by Saran et al. (28).

Other topics besides oral carcinogenesis were investigated using the single-cell gel comet assay on oral cells. It is important to stress that some studies have focused on genotoxicity due to environmental pollution, seven to date. Similarly, a total of 11 studies investigated the genotoxic effect of chemicals or drugs (legal or illegal) on the oral mucosa, such as: nandrolone decanoate (29), pesticides (30), car paints (31) and anti-neoplastic drugs (32). VasquezBoucard et al. postulated harmful effects of continuous exposure to water/tap water contaminated by organochlorine pesticides and heavy metals in Mexico (33). By contrast, the authors failed to establish a dose-response relationship between pollution and genotoxicity on oral mucosa cells (33). Other pollutants have been investigated, such as air pollution (34), and other settings such as occupational exposure of airport personnel (35) and battery renovation workers (36). In summary, it appears that the oral mucosa is very sensitive to anthropogenic activities, especially to pollutants present in the environment.

Finally, some chemopreventive studies against genotoxicity induced in oral cells were found. The most significant were those related to black tea and tobacco smoke (37); epigallocatechin-3-gallate and smoke (38); histone acetylase inhibitor for therapeutics (39); and Pteridium aquilinum extract against oral cancer cells (40). To the best of our knowledge, only two articles investigated the genotoxicity induced by cannabimimetic drug (41) and radiation (42) in oral cells by comet assay. In the same way, one article investigated genotoxicity induced by aging (43). A total of two articles investigated the genotoxic effects of fluoride on buccal mucosa in rodents, with controversial results $(44,45)$.

\section{Conclusion}

Overall, this study found there have been recent advances in the application of single-cell gel assay of oral cells in humans, but few were based on studies in rodents and in vitro. Therefore, new studies within the field are important for better understanding the underlying mechanisms of genotoxicity in oral cells, especially since such studies on humans are not allowed due to ethical considerations. It would then be possible to correlate the analyses from different animal species and experimental designs in order to validate methodology as a reproducible approach for biomonitoring human health.

\section{Acknowledgements}

LPP, MBV and DAR are researchers on Productivity at CNPq (National Council for Scientific and Technological Development). VQY is a recipient of CNPq scholarship (Ph.D. level).

\section{Conflicts of Interest}

None declared.

\section{Authors' Contributions}

Research project conception: ACFS and DAR. Search of the literature: ACFS and VQY. Data analysis: ACFS, LPP, MBV, GMC and DAR. Writing the paper: all authors.

\section{References}

1 Jackon SP and Bartek J: The DNA-damage response in human biology and disease. Nature 461(7267): 1071-1078, 2009. PMID: 19847258.

2 Johnson MD, Schilz J, Djordjevic MV, Rice JR and Shields PG: Evaluation of in vitro assays for assessing the toxicity of cigarette smoke and smokeless tobacco. Cancer Epidemiol Biomarkers Prev 18(12): 3263-304, 2009. PMID: 19959677. DOI: 10.1158/1055-9965.EPI-09-0965

3 Tice RR, Agurell E, Anderson D, Burlinson B, Hartmann A, Kobayashi H, Miyamae Y, Rojas E, Ryu JC and Sasaki YF: Single-cell gel/comet assay: guidelines for in vitro and in vivo genetic toxicology testing. Environ Mol Mutagen 35(3): 206221, 2000. PMID: 10737956

4 Ostling $\mathrm{O}$ and Johanson KJ: Microelectrophoretic study of radiation-induced DNA damages in individual mammalian cells. Biochem. Biophys. Res Commun 123: 291-298, 1984. PMID: 6477583. DOI: $10.1016 / 0006-291 x(84) 90411-x$ 
5 Singh NP, McCoy MT, Tice RR and Schneider EL: A simple technique for quantitation of low levels of DNA damage in individual cells. Exp Cell Res 175: 184-191, 1988. PMID: 3345800.

6 McKelvey-Martin VJ, Green MH, Schmezer P, Pool- Zobel BL, De Meo MP and Collins MPA: The single-cell gel electrophoresis assay (comet assay): A European review. Mutat Res 288: 47-63, 1993. PMID: 7686265.

7 Collins AR, Dusinska M, Gedik CM and Stetina R: Oxidative damage to DNA: do we have a reliable biomarker? Environ. Health Perspect 104: 465-469, 1996. PMID: 8781365. DOI: 10.1289/ehp.96104s3465

8 Collins AR: The comet assay. Principles, applications, and limitations, Meth Mol Biol 203: 163-177, 2002. PMID: 12073440

9 Szeto YT, Benzie IF, Collins AR, Choi SW, Cheng CY, Yow CM and Tse MM: A buccal cell model comet assay: Development and evaluation for human biomonitoring and nutritional studies. Mutat Res 578(1-2): 371-381, 2005. PMID: 16085124. DOI: 10.1016/j.mrfmmm.2005.06.014

10 Benvindo-Souza M, Assis RA, Oliveira EAS, Borges RE and Santos LRS: The micronucleus test for the oral mucosa: Global trends and new questions. Environ Sci Pollut Res Int 24(36): 27724-27730, 2017. PMID: 29152700. DOI: 10.1007/s11356017-0727-2

11 Rojas E, Valverde M, Sordo M and Ostrosky-Wegman P: DNA damage in exfoliated buccal cells of smokers assessed by the single-cell gel electrophoresis assay. Mutat Res 370(2): 115-120, 1996. PMID: 8879269.

12 Pinhal D, Gontijo AM, Reyes VA and Salvadori DM: Viable human buccal mucosa cells do not yield typical nucleoids: impacts on the single-cell gel electrophoresis/Comet assay. Environ Mol Mutagen 47(2): 117-126, 2006. PMID: 16258922. DOI: $10.1002 / \mathrm{em} .20174$

13 Osswald K, Mittas A, Glei M and Pool-Zobel BL: New revival of an old biomarker: Characterisation of buccal cells and determination of genetic damage in the isolated fraction of viable leucocytes. Mutat Res 544(2-3): 321-329, 2003. PMID: 14644334.

14 Faccioni P, De Santis D, Sinigaglia S, Pancera P, Faccioni F and Nocini PF: Short-term "in vivo" study on cellular DNA damage induced by acrylic Andresen activator in oral mucosa cells. Orthod Craniofac Res, 2019. PMID: 30908883. DOI: 10.1111/ ocr.12312

15 Faccioni F, Franceschetti P, Cerpelloni M and Fracasso ME: In vivo study on metal release from fixed orthodontic appliances and DNA damage in oral mucosa cells. Am J Orthod Dentofacial Orthop 124(6): 687-694, 2003. PMID: 14666083. DOI: 10.1016/ S0889540603007418

16 Kapadia JM, Agarwal AR, Mishra S, Joneja P, Yusuf AS and Choudhary DS: Cytotoxic and genotoxic effect on the buccal mucosa cells of patients undergoing fixed orthodontic treatment. J Contemp Dent Pract 19(11): 1358-1362, 2018. PMID: 14666 083 DOI: $10.1016 / \mathrm{S} 0889540603007418$

17 Fernández-Miñano E, Ortiz C, Vicente A, Calvo Guirado JL and Ortiz AJ: Metallic ion content and damage to the DNA in oral mucosa cells of children with fixed orthodontic appliances. Biometals 24(5): 935, 2011. PMID: 21468621. DOI: 10.1007/ s10534-011-9448-z.

18 Westphalen GH, Menezes LM, Prá D, Garcia GG, Schmitt VM, Henriques JA and Medina-Silva R: In vivo determination of genotoxicity induced by metals from orthodontic appliances using micronucleus and comet assays. Genet Mol Res 7(4): 1259-1266, 2008. PMID: 19065761.
19 Fox SA, Currie SS, Dalley AJ and Farah CS: Transcriptome changes induced in vitro by alcohol-containing mouthwashes in normal and dysplastic oral keratinocytes. J Oral Pathol Med 47(5): 511-518, 2018. PMID: 29504154. DOI: 10.1111/jop. 12704

20 Eren K, Ozmeriç N and Sardaş S: Monitoring of buccal epithelial cells by alkaline comet assay (single-cell gel electrophoresis technique) in cytogenetic evaluation of chlorhexidine. Clin Oral Investig 6(3): 150-154, 2002. PMID: 12271347. DOI: 10.1007/s00784-002-0168-1

21 Ribeiro DA, Bazo AP, da Silva Franchi CA, Marques ME and Salvadori DM: Chlorhexidine induces DNA damage in rat peripheral leukocytes and oral mucosal cells. J Periodontal Res 39(5): 358-361, 2004. PMID: 15324357. DOI: 10.1111/j.16000765.2004.00759.x

22 Ribeiro DA, Fávero Salvadori DM, da Silva RN, Ribeiro Darros $\mathrm{B}$ and Alencar Marques ME: Genomic instability in nonneoplastic oral mucosa cells can predict risk during 4nitroquinoline 1-oxide-induced rat tongue carcinogenesis. Oral Oncol 40(9): 910-915, 2004. PMID: 15380169. DOI: 10.1016/ j.oraloncology.2004.04.010

23 Carvalho JG, Noguti J, da Silva VH, Dedivitis RA, Franco M and Ribeiro DA: Alkylation-induced genotoxicity as a predictor of DNA repair deficiency following experimental oral carcinogenesis. J Mol Histol 43(2): 145-150, 2012. PMID: 2228 7026. DOI: $10.1007 / \mathrm{s} 10735-011-9388-5$

24 Miranda SR, Noguti J, Carvalho JG, Oshima CT and Ribeiro DA: Oxidative DNA damage is a preliminary step during rat tongue carcinogenesis induced by 4-nitroquinoline 1-oxide. J Mol Histol 42(2): 181-186, 2011. PMID: 21431370. DOI: 10.1007/s10735-011-9323-9

25 Glei M, Habermann N, Osswald K, Seidel C, Persin C, Jahreis $\mathrm{G}$ and Pool-Zobel BL: Assessment of DNA damage and its modulation by dietary and genetic factors in smokers using the Comet assay: a biomarker model. Biomarkers 10(2-3): 203-217, 2005. PMID: 16076733. DOI: 10.1080/13547500500138963

26 Al-Amrah HJ. Aboznada OA, Alam MZ, ElAssouli MZ, Mujallid MI and El Assouli SM: Genotoxicity of waterpipe smoke in buccal cells and peripheral blood leukocytes as determined by comet assay. Inhal Toxicol 26(14): 891-896, 2014. PMID: 25357232. DOI: 10.3109/08958378.2014.970787.

27 Mukherjee S, Ray JG and Chaudhuri K: Evaluation of DNA damage in oral precancerous and squamous cell carcinoma patients by single-cell gel electrophoresis. Indian J Dent Res 22(5): 735-736, 2011. PMID: 22406732. DOI: 10.4103/09709290.93475

28 Saran R, Tiwari RK, Reddy PP and Ahuja YR: Risk assessment of oral cancer in patients with pre-cancerous states of the oral cavity using micronucleus test and challenge assay. Oral Oncol 44(4): 354-360, 2008. PMID: 17936677.

29 Pozzi R, Fernandes KR, Foot Gomes de Moura C, Ferrari RA, Fernandes KP, Chaves MD, Renno AC and Ribeiro DA: DNA damage, p53, Ki-67 and COX-2 expression in rat tongue cells exposed to nandrolone decanoate. Toxicol Mech Methods 23(4): 289-296, 2013. PMID: 23210612. DOI: 10.3109/15376516.2012. 755594

30 How V, Hashim Z, Ismail P, Omar D, Said SM and Tamrin SB: Characterization of risk factors for DNA damage among paddy farm worker exposed to mixtures of organophosphates. Arch Environ Occup Health 70(2): 102-109, 2015. PMID: 24965330. DOI: $10.1080 / 19338244.2013 .823905$ 
31 de Oliveira HM, Dagostim GP, da Silva AM, Tavares P, da Rosa LA and de Andrade VM: Occupational risk assessment of paint industry workers. Indian J Occup Environ Med 15(2): 52-58, 2011. PMID: 22223950. DOI: 10.4103/0019-5278.90374

32 Ursini CL, Cavallo D, Colombi A, Giglio M, Marinaccio A and Iavicoli S: Evaluation of early DNA damage in healthcare workers handling antineoplastic drugs. Int Arch Occup Environ Health 80(2): 134-140, 2006. PMID: 16761155. DOI: 10.1007/ s00420-006-0111-x

33 Vazquez Boucard C, Lee-Cruz L, Mercier L, Ramírez Orozco M, Serrano Pinto V, Anguiano G, Cazares L and Díaz D: A study of DNA damage in buccal cells of consumers of well- and/or tap-water using the comet assay: Assessment of occupational exposure to genotoxicants. Environ Mol Mutagen 58(8): 619627, 2017. PMID: 28714172. DOI: 10.1002/em.22111

34 Mondal NK, Bhattacharya P and Ray MR: Assessment of DNA damage by comet assay and fast halo assay in buccal epithelial cells of Indian women chronically exposed to biomass smoke. Int J Hyg Environ Health 214(4): 311-318, 2011. PMID: 21550302. DOI: 10.1016/j.ijheh.2011.04.003

35 Cavallo D, Ursini CL, Carelli G, Iavicoli I, Ciervo A, Perniconi B, Rondinone B, Gismondi $\mathrm{M}$ and Iavicoli S: Occupational exposure in airport personnel: characterization and evaluation of genotoxic and oxidative effects. Toxicology 223(1-2): 26-35, 2006. PMID: 16621217. DOI: 10.1016/j.tox.2006.03.003

36 Martino-Roth MG, Viégas J and Roth DM: Occupational genotoxicity risk evaluation through the comet assay and the micronucleus test. Genet Mol Res 2(4): 410-417, 2003. PMID: 15011144.

37 Pal D, Sur S, Mandal S, Das S and Panda CK: Regular black tea habit could reduce tobacco associated ROS generation and DNA damage in oral mucosa of normal population. Food Chem Toxicol 50(9): 2996-3003, 2012. PMID: 22705326. DOI: 10.1016/j.fct.2012.06.005

38 Baumeister P, Reiter M, Kleinsasser N, Matthias C, Harréus U: Epigallocatechin-3-gallate reduces DNA damage induced by benzo[a]pyrene diol epoxide and cigarette smoke condensate in human mucosa tissue cultures. Eur J Cancer Prev 18(3): 230235, 2009. PMID: 19491610. DOI: 10.1097/CEJ.0b013e $32831 \mathrm{bc} 3 \mathrm{a} 0$

39 Chung YL, Lee MY and Pui NN: Epigenetic therapy using the histone deacetylase inhibitor for increasing therapeutic gain in oral cancer: prevention of radiation-induced oral mucositis and inhibition of chemical-induced oral carcinogenesis. Carcinogenesis 30(8): 1387-1397, 2009. PMID: 19351790. DOI: 10.1093/carcin/bgp079

40 Pereira LO, Bicalho LS, Campos-da-Paz Lopes M, de Sousa TM, Báo SN, de Fátima Menezes Almeida Santos M and Fonseca MJ: DNA damage and apoptosis induced by Pteridium aquilinum aqueous extract in the oral cell lines HSG and OSCC3. J Oral Pathol Med 38(5): 441-447, 2009. PMID: 19175853. DOI: $10.1111 / \mathrm{j} .1600-0714.2008 .00705 . x$

41 Koller VJ, Auwärter V, Grummt T3, Moosmann B, Mišík M and Knasmüller $\mathrm{S}$ : Investigation of the in vitro toxicological properties of the synthetic cannabimimetic drug CP-47,497-C8. Toxicol Appl Pharmacol 277(2): 164-171, 2014. PMID: 24686252. DOI: 10.1016/j.taap.2014.03.014

42 Dhillon VS, Thomas P and Fenech M: Comparison of DNA damage and repair following radiation challenge in buccal cells and lymphocytes using single-cell gel electrophoresis. Int $\mathbf{J}$ Radiat Biol 80(7): 517-528, 2004. PMID: 5360090.
43 Eshkoor SA, Ismail P, Rahman SA, Adon MY and Devan RV: Contribution of CYP2E1 polymorphism to aging in the mechanical workshop workers. Toxicol Mech Methods 23(4): 217-222, 2013. PMID: 23193996. DOI: 10.3109/15376516. 2012.743637

44 Ribeiro DA, Marques ME, de Assis GF, Anzai A, Poleti ML and Salvadori DM: No relationship between subchronic fluoride intake and DNA damage in Wistar rats. Caries Res 38(6): 576579, 2004. PMID: 15528915. DOI: $10.1159 / 000080590$

$45 \mathrm{He}$ LF and Chen JG: DNA damage. apoptosis and cell cycle changes induced by fluoride in rat oral mucosal cells and hepatocytes. World J Gastroenterol 12(7): 1144-1148, 2006. PMID: 16534862. DOI: 10.3748/wjg.v12.i7.1144

46 Carbajal-López Y, Gómez-Arroyo S, Villalobos-Pietrini R, Calderón-Segura ME and Martínez-Arroyo A: Biomonitoring of agricultural workers exposed to pesticide mixtures in Guerrero state, Mexico, with comet assay and micronucleus test. Environ Sci Pollut Res Int 23(3): 2513-2520, 2016. PMID: 26423288. DOI: $10.1007 / \mathrm{s} 11356-015-5474-7$

47 Gonçalves TS, Menezes LM, Trindade C, Thomas P, Fenechc M and Henriques JA: In vivo evaluation of the genotoxic effects of Hyrax auxiliary orthodontic appliances containing silversoldered joints. Mutat Res Genet Toxicol Environ Mutagen 791: 25-29, 2015. PMID: 26338539. DOI: 10.1016/j.mrgentox. 2015.07.007

48 Wessels M, Rimkus J, Leyhausen G, Volk J and Geurtsen W: Genotoxic effects of camphorquinone and DMT on human oral and intestinal cells. Dent Mater 31(10): 1159-1168, 2015. PMID: 26187530. DOI: 10.1016/j.dental.2015.06.007

49 Martín-Cameán A, Puerto M, Jos Á, Azqueta A, Iglesias-Linares A, Solano E and Cameán AM: Preliminary study of genotoxicity evaluation of orthodontic miniscrews on mucosa oral cells by the alkaline comet assay. Toxicol Mech Methods 25(6): 487-493, 2015. PMID: 26062010. DOI: 10.3109/15376516.2015.1053652

50 Bhagwath SS and Chandra L: Assessing extent of singlestranded DNA damage in oral mucosal cells of patients with oral squamous cell carcinoma and its correlation with TNM staging. Indian J Dent Res 25(5): 555-558, 2014. PMID: 25511050. DOI: 10.4103/0970-9290.147075

51 Feretti D, Ceretti E, De Donno A, Moretti M, Carducci A, Bonetta S, Marrese MR, Bonetti A, Covolo L, Bagordo F, Villarini M, Verani M, Schilirò T, Limina RM, Grassi T, Monarca S, Casini B, Carraro E, Zani C, Mazzoleni G, Levaggi $\mathrm{R}$ and Gelatti U and MAPEC_LIFE Study Group: Monitoring air pollution effects on children for supporting public health policy: The protocol of the prospective cohort MAPEC study. BMJ Open 4(9): e006096, 2014. PMID: 25227631. DOI: 10.1136/bmjopen-2014-006096

52 Visalli G, Baluce B, La Maestra S, Micale RT, Cingano L, De Flora S, Di Pietro A: Genotoxic damage in the oral mucosa cells of subjects carrying restorative dental fillings. Arch Toxicol 87(1): 179-187, 2013. PMID: 22872142.

53 Szeto YT, Lee AK, Benzie IF and Obied HK: Optimized noninvasive procedures to measure DNA damage in comet assay. Hum Exp Toxicol 31(11): 1144-1150, 2012. PMID: 22653686. DOI: $10.1177 / 0960327112446816$

54 Dodani K, Anumala N, Avula H, Reddy K, Varre S, Kalakonda BB, Arora N, Suri C and Avula JK: Periodontal findings in patients with oral submucous fibrosis and comet assay of affected gingival epithelial cells. J Periodontol 83(8): 1038-1047, 2012. PMID: 22166165. DOI: 10.1902/jop.2011.110352 
55 Baričević M, Ratkaj I, Mladinić M, Zelježić D, Kraljević SP, Lončar B and Stipetić MM: In vivo assessment of DNA damage induced in oral mucosa cells by fixed and removable metal prosthodontic appliances. Clin Oral Investig 16(1): 325-331, 2012. PMID: 21120674. DOI: 10.1007/s00784-010-0489-4

56 Sudha S, Kripa SK, Shibily P, Joseph S and Balachandar V: Biomonitoring of genotoxic effects among shielded manual metal arc welders. Asian Pac J Cancer Prev 12(4): 1041-1044, 2011. PMID: 21790248.

57 Muniz JF, McCauley LA, Pak V, Lasarev MR and Kisby GE: Effects of sample collection and storage conditions on DNA damage in buccal cells from agricultural workers. Mutat Res 720(1-2): 8-13, 2011. PMID: 21138773. DOI: 10.1016/j. mrgentox.2010.11.010

58 Reiter M, Welz C, Baumeister P, Schwenk-Zieger S and Harréus $\mathrm{U}$ : Mutagen sensitivity and DNA repair of the EGFR gene in oropharyngeal cancer. Oral Oncol 46(7): 519-524, 2010. PMID: 20400363. DOI: 10.1016/j.oraloncology.2010.03.019

59 Baumeister P, Schwenk-Zieger S, Reiter M, Welz C and Harréus $\mathrm{U}$ : Transforming growth factor-alpha reduces carcinogeninduced DNA damage in mini-organ cultures from head-andneck cancer patients. Mutat Res 677(1-2): 42-45, 2009. PMID: 19539778. DOI: 10.1016/j.mrgentox.2009.05.019
60 Kleinsasser NH, Wallner BC, Kastenbauer ER, Weissacher H and Harréus UA: Genotoxicity of di-butyl-phthalate and di-iso-butylphthalate in human lymphocytes and mucosal cells. Teratog Carcinog Mutagen 21(3): 189-196, 2001. PMID: 11301413.

61 Tomakidi P, Koke U, Kern R, Erdinger L, Krüger H, Kohl A and Komposch G: Assessment of acute cyto- and genotoxicity of corrosion eluates obtained from orthodontic materials using monolayer cultures of immortalized human gingival keratinocytes. J Orofac Orthop 61(1): 2-19, 2000. PMID: 10682407.
Received May 22, 2019

Revised June 18, 2019

Accepted June 21, 2019 